Contemporary British Fascism 
Also by Nigel Copsey

ANTI-FASCISM IN BRITAIN

BRITISH FASCISM, THE LABOUR MOVEMENT AND THE STATE (with D. Renton) 


\section{Contemporary British Fascism}

The British National Party and the Quest for Legitimacy

Nigel Copsey

Reader in Modern History, University of Teesside, UK

Second Edition

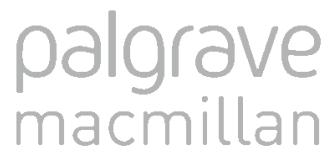




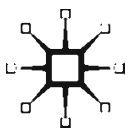

(C) Nigel Copsey 2004, 2008

Softcover reprint of the hardcover 1st edition 2008 978-0-230-57436-6

All rights reserved. No reproduction, copy or transmission of this publication may be made without written permission.

No paragraph of this publication may be reproduced, copied or transmitted save with written permission or in accordance with the provisions of the Copyright, Designs and Patents Act 1988, or under the terms of any licence permitting limited copying issued by the Copyright Licensing Agency, 90 Tottenham Court Road, London W1T 4LP.

Any person who does any unauthorised act in relation to this publication may be liable to criminal prosecution and civil claims for damages.

The author has asserted his right to be identified as the author of this work in accordance with the Copyright, Designs and Patents Act 1988.

First edition published 2004

Second edition published 2008

PALGRAVE MACMILLAN

Houndmills, Basingstoke, Hampshire RG21 6XS and

175 Fifth Avenue, New York, N. Y. 10010

Companies and representatives throughout the world

PALGRAVE MACMILLAN is the global academic imprint of the Palgrave Macmillan division of St. Martin's Press, LLC and of Palgrave Macmillan Ltd. Macmillan ${ }^{\circledR}$ is a registered trademark in the United States, United Kingdom and other countries. Palgrave is a registered trademark in the European Union and other countries.

ISBN 978-0-230-57437-3 ISBN 978-0-230-22785-9 (eBook)

DOI $10.1057 / 9780230227859$

This book is printed on paper suitable for recycling and made from fully managed and sustained forest sources. Logging, pulping and manufacturing processes are expected to conform to the environmental regulations of the country of origin.

A catalogue record for this book is available from the British Library.

Library of Congress Cataloging-in-Publication Data

Copsey, Nigel, 1967-

Contemporary British fascism : the British National Party and the quest for legitimacy / Nigel Copsey.

p. $\quad \mathrm{cm}$. - (Reader in modern history)

Includes bibliographical references and index.

ISBN 978-0-230-57437-3 (pbk.)

1. British National Party (1982- ～） 2. Political parties - Great Britain.

3. Fascism - Great Britain. I. Title.

JN1129.B75C67 2008

324.241'0938-dc22

2008016143

$\begin{array}{rrrrrrrrrr}10 & 9 & 8 & 7 & 6 & 5 & 4 & 3 & 2 & 1\end{array}$

$\begin{array}{llllllllll}17 & 16 & 15 & 14 & 13 & 12 & 11 & 10 & 09 & 08\end{array}$ 


\section{Contents}

Acknowledgements vii

$\begin{array}{lr}\text { Introduction } & 1\end{array}$

1 'Back to Front': John Tyndall and the Origins of the 6 British National Party

From League of Empire Loyalist to National Socialist $\quad 7$

Emerging from the British führer's shadow: from the 12

National Socialist Movement to the National Front

Schism at the 'gay' National Front and the birth of the $\quad 21$

British National Party

2 The Struggle for the Soul of British Nationalism 29

Establishing itself: the BNP in its early years 29

The holy grail of 'Nationalist Unity': the British National 33

Party and the challenge of the National Front, 1983-87

On or off? The BNP and the electoral trail 39

The 1980s draw to a close: the BNP at the end of the road? 42

3 A False Dawn in Tower Hamlets: The British National 51

Party in the 1990s

Making gains at the ballot box $\quad 52$

'Rights for whites': the BNP and the quest for local legitimacy 56

London's 'secret racists': a helping hand from elsewhere 61

The false dawn 66

Manoeuvring towards the leadership contest 69

4 Fascism on the Fringe: The Ideology of Tyndall's British 76

National Party

$\begin{array}{ll}\text { Conceptualising right-wing extremism } & 77\end{array}$

Fascism: the revolutionary ideology of the extreme right 80

$\begin{array}{ll}\text { In search of revolutionary rebirth } & 82\end{array}$

The racial fascism of the British National Party 87

On the Jewish question $\quad 91$

'Neither capitalism nor socialism': the British National 93

Party and the new economic order

Conclusion: a contemporary British fascism 
5 New Millennium New Leader: Nick Griffin and the

Modernisation of the British National Party, 1999-2001

Responsibility

Professionalism

Slinging mud and electing the leader

Griffin takes charge

Modernisation de-railed?

6 Out of Obscurity: The Rise of the British National Party, 2001-2003

Oldham, Burnley and the 2001 General Election

Courting the media, winning votes and getting elected

'The genie is out of the bottle'

'We don't just win in Lancashire'

7 Successes and Setbacks: The British National Party since 2004

Frustrated expectations: the June 2004 elections

'Breaking with the past'

National-populism or neo-fascism?

'Their finest hour': the 2006 local elections

'Target 100': the 2007 local elections and beyond

8 The British National Party in Comparative Perspective

\section{Conclusion}

Notes

Select Bibliography 


\section{Acknowledgements}

In the first place, my thanks go to those people whose assistance proved especially valuable when it came to collecting research materials for this book. They are Martin Durham, Monty Kolsky at the Board of Deputies of British Jews, Mike Hartman from the Tyne and Wear Anti-Fascist Association, Graham Macklin, Paul Meszaros from Bradford Trades Council, and Christine Woodland, Archivist at the University of Warwick's Modern Records Centre. My thanks also go to an anonymous source for granting me access to his private research collection and to Michael Newland for answering my queries. David Renton commented on parts of the original manuscript and Graham Macklin on the revised version. I am grateful to both for their suggestions and advice. For permission to re-use material from prior publications, I acknowledge the Political Studies Association, Blackwell, and Taylor and Francis (Routledge). As always, I owe a special thanks to Ali and my family for their encouragement and forbearance.

Nigel COPSEY 